\title{
The Influence of Some Welding Parameters on the Properties of Stainless Steel Strip Cladding Deposited by a Submerged Arc Process
}

\author{
By P. K. Ghosh*, P. C. Gupta*, M. Breazu* \\ and R. K. Gupta*
}

\begin{abstract}
Single pass clad layers of stainless steel on $15 \mathrm{~mm}$ thick carbon steel plates have been deposited by submerged arc strip welding carried out at different welding parameters. The influences of the welding current and arc voltage on the thickness of the clad layer, the ferrite content of the clad surface and the variation in microhardness of the weld have been studied. The thickness of the deposited layer has been found to increase with the increase of welding current and to remain nearly unchanged with the increase of arc voltage. The increase in welding current and also in arc voltage reduces the ferrite content of the clad surface. The extent of ferrite level depends parimarily upon the chemical composition of the deposited layer which in turn is influenced by the amount of heat input. A transition region having a comparatively higher hardness than that of its surrounding has been found to form at the clad to base metal interface. The hardness of the interface has been found to be raised even up to an order of about 450 VHN during welding with a heat input within the range of about $11-12 \mathrm{~kJ} / \mathrm{mm}$.
\end{abstract}

(Received March 16, 1987)

Keywords: submerged arc, stainless steel strip cladding, bead height, ferrite content, interface, micro hardness

\section{Introduction}

The protection of the primary structure from corrosion is of prime concern in the vessels used in corrosive environment. Out of various corrosion protective measures used in steel structures, the employment of a corrosion resistant weld clad layer on the steel surface which is to be exposed to corrosion environment is given wide attention ${ }^{(1)-(3)}$. The popularity of the weld clad process lies in its versatility with regards to its applications, quality of cladding in comparison to that obtained by other cladding processes and longer life of the clad layer. For weld cladding of large assemblies the submerged-arc strip cladding process is in extensive use due to the excellent deposit properties coupled with restricted penetration at a higher deposition rate ${ }^{(3)-(5)}$.

The control of chemical composition and microstructure of the resulting weld-clad layer

* Welding Research Laboratory, Department of Mechanical and Industrial Engineering, University of Roorkee, Roorkee-247667, India. is of utmost importance for achieving a good corrosion resistance. The variation in welding parameters influences the dilution behaviour of the weld $\mathrm{d}^{(6)(7)}$ and subsequently affects the ferrite content of the deposit and the corrosion resistance of the single pass clad layer ${ }^{(3)(8)}$.

The mechanical properties of the clad to base metal transition region is of considerable importance, especially in the case of applications in the pressure vessel which are subjected to a cyclic thermal and mechanical stressing. In joints between austenitic stainless steel and low alloy or unalloyed carbon steel the carbon diffusion and mixing of materials play a significant role in determining the mechanical properties of the transition region ${ }^{(9)}$. The formation of the interacted zone at the interface of the stainless steel and unalloyed or alloyed carbon steel can be favoured during cladding on a base plate of comparatively lower thickness by submerged arc welding process due to its excessive heating, intense chemical and metallurgical activities occur in the transition zone.

In this work an investigation has been carried out on the effects of welding current and 
arc voltage on the ferrite content at the surface of the cladding, the bead height and the microhardness behaviour across the interface of cladding.

\section{Experimental}

The stainless steel cladding layer was deposited by the submerged arc welding process on the mechanically cleaned surface of 15 $\mathrm{mm}$ thick mild steel plates having dimensions of $15 \times 90 \times 240(\mathrm{~mm})$. The chemical compositions of the mild steel plates, the stainless steel strip (L 21/10) of crossection $60 \mathrm{~mm} \times 0.5 \mathrm{~mm}$ and the neutral flux (LW-410) used in this work are shown in Tables 1,2 and 3 respectively.

To avoid distortion the base plate was properly tacked to a $30 \mathrm{~mm}$ thick steel plate. Before use, the flux was baked for $9 \times 10^{3} \mathrm{~s}(2.5 \mathrm{~h})$ at $523 \mathrm{~K}$. The strip electrode was connected to the positive terminal of the rectifier. The length of deposit in each case was about $200 \mathrm{~mm}$. The cladding was carried out by varying the welding current in the range of 550-1000 A when the arc voltage and the welding speed (Travel) were kept at $28 \mathrm{~V}$ and $2 \mathrm{~mm} / \mathrm{s}$ respectively and by varying the arc voltage in the

Table 1 Chemical composition of base metal.

\begin{tabular}{lccccc}
\hline \multirow{2}{*}{ Material } & \multicolumn{6}{c}{ Chemical composition (mass\%) } \\
\cline { 2 - 6 } & $\mathrm{C}$ & $\mathrm{Si}$ & $\mathrm{Mn}$ & $\mathrm{S}$ & $\mathrm{P}$ \\
\hline $\begin{array}{c}\text { Mild steel } \\
\text { base plate }\end{array}$ & 0.16 & 0.05 & 1.1 & 0.03 & 0.02 \\
\hline \hline
\end{tabular}

Table 2 Chemical composition of strip electrode.

\begin{tabular}{lccccc}
\hline \multirow{2}{*}{ Material } & \multicolumn{6}{c}{ Chemical composition (mass\%) } \\
\cline { 2 - 6 } & $\mathrm{Cr}$ & $\mathrm{Ni}$ & $\mathrm{Mn}$ & $\mathrm{Si}$ & $\mathrm{C}$ \\
\hline $\begin{array}{c}\text { Stainless steel } \\
\text { strip electrode }\end{array}$ & 21.0 & 10.0 & 2.2 & 0.3 & 0.02 \\
\hline \hline
\end{tabular}

range of 24-34 V when the welding current and the welding speed were kept at $750 \mathrm{~A}$ and 2 $\mathrm{mm} / \mathrm{s}$ respectively. The effects of welding current and arc voltage on the bead height and the ferrite content at the surface of the stainless steel overlay have been studied. The variation in the microhardness across the interface of cladding made by using the lowest and the highest welding current and arc voltage have been estimated.

For estimation of ferrite content at the surface of the cladding, the whole surface area leaving about $15 \mathrm{~mm}$ from both ends of the overlay was graduated into the cells of 15 $\mathrm{mm} \times 15 \mathrm{~mm}$. In each cell the ferrite content was measured with the help of a ferrite meter capable to estimate the ferrite level directly in percent. The arithmetic mean and the standard deviation of the ferrite content values so obtained from different cells were determined for individual welds and have been reported for welds at different welding parameters.

The transverse section of the claded plates made at different welding parameters were prepared by the standard metallographic procedure for microscopic observation. The specimens were etched in $2 \%$ nital solution to reveal the fusion line and the bead height was estimated under the microscope. To study the microstructure of stainless steel cladding the specimens were etched in a solution containing nitric acid $\left(10 \mathrm{~cm}^{3}\right)$, acetic acid $\left(10 \mathrm{~cm}^{3}\right)$, Glycerol $\left(5 \mathrm{~cm}^{3}\right)$ and hydrochloric acid $(15$ $\mathrm{cm}^{3}$ ).

The microhardness across the interface of the etched transversection of the clad plates made at different welding parameters were estimated by using a load of $784 \mathrm{~N}$ ( $80 \mathrm{kgf}$ ). The microhardness of the base metal and its heat affected zone were estimated by indenting on the ferrite phase. The microhardness behaviour of the claded plates along a path

Table 3 Chemical composition of flux.

\begin{tabular}{lcccccc}
\hline \multirow{2}{*}{ Material } & \multicolumn{5}{c}{ Chemical composition (mass\%) } \\
\cline { 2 - 7 } & $\mathrm{SiO}_{2}+\mathrm{TiO}_{2}$ & $\mathrm{CaO}+\mathrm{MgO}$ & $\mathrm{Al}_{2} \mathrm{O}_{3}$ & $\mathrm{P}$ & $\mathrm{S}$ & $\mathrm{Na}_{3} \mathrm{AlF}_{6}$ \\
\hline $\begin{array}{c}\text { Flux } \\
(\mathrm{LW}-410)\end{array}$ & 45 & 40 & 8 & 0.003 & 0.002 & 8 \\
\hline \hline
\end{tabular}


Influence of Some Welding Parameters on Properties of Stainless Steel Strip Cladding Deposited by SAW Process 581

Table 4 Chemical compositions of the stainless steel weld overlay under different welding parameters.

\begin{tabular}{cccccccc}
\hline \hline \multirow{2}{*}{$\begin{array}{c}\text { Welding } \\
\text { current } \\
\text { (A) }\end{array}$} & $\begin{array}{c}\text { Arc } \\
\text { voltage } \\
\text { (V) }\end{array}$ & $\begin{array}{c}\text { Travel } \\
\text { speed } \\
\mathrm{mm} / \mathrm{s}\end{array}$ & $\mathrm{Cr}$ & $\mathrm{Ni}$ & $\mathrm{C}$ & $\mathrm{Mn}$ & $\mathrm{Si}$ \\
\hline 550 & 28 & 2 & 17.6 & 8.6 & 0.04 & 0.96 & 0.9 \\
750 & 28 & 2 & 17.2 & 8.4 & 0.045 & 0.92 & 0.86 \\
1000 & 28 & 2 & 16.8 & - & 0.05 & 1.02 & 0.8 \\
750 & 24 & 2 & 17.8 & 8.1 & 0.05 & - & 0.72 \\
750 & 26 & 2 & 17.7 & 8.1 & - & 0.93 & 0.81 \\
750 & 34 & 2 & 16.9 & 8.5 & 0.06 & 0.87 & 0.99 \\
\hline \hline
\end{tabular}

perpendicular to the interface starting from close to the boundary of the cladding up to a certain extent in base metal has been reported.

For chemical analysis the samples were collected from the surface of the stainless steel cladding made at different welding parameters and were analysed by a vacuum emission spectrometer.

\section{Results}

The chemical compositions of the stainless steel claddings made at different welding parameters given in Table 4 shows that during cladding of stainless steel the chromium, nickel and manganese contents of the deposited metal are significantly lowered whereas the carbon and silicon contents are increased as revealed from the comparison of the chemical compositions of the stainless strip electrode given in Table 2 and that of weld deposit given in Table 4. It has also been observed that the extent of the lowering of chromium, nickel and manganese and the extent of the gain of carbon and silicon in stainless steel cladding depends upon the welding parameters as given in Table 4.

The effect of welding current at a given arc voltage and travel speed on the ferrite level at the cladding surface presented in Fig. 1 shows that with the increase in welding current up to 750 A the ferrite content reduces significantly followed by a slower rate of reduction with a further enhancement of welding current up to 950 A. However, the rate of decrease of ferrite content with the increase of welding current has been found to be enhanced significantly with the increase of current from $950 \mathrm{~A}$ to
$1000 \mathrm{~A}$. Also with the increase in welding current the bead height of the stainless steel overlay increases.

The variation in ferrite content on the surface of stainless steel cladding with the increase in arc voltage at a given welding current and travel speed shown in Fig. 2 depicts that the increase in arc voltage from $24 \mathrm{~V}$ to $26 \mathrm{~V}$ does not influence much the ferrite level of the cladding. However a further increase in arc voltage up to $32 \mathrm{~V}$ has been found to reduce significantly the ferrite content of the cladding. Between 32 and $34 \mathrm{~V}$ the ferrite level of cladding remains more or less same. Under the given condition of other welding parameters as mentioned above the increase in arc voltage from 24 to $34 \mathrm{~V}$ does not show (Fig. 2) any significant effect on the variation in the bead height of the cladding.

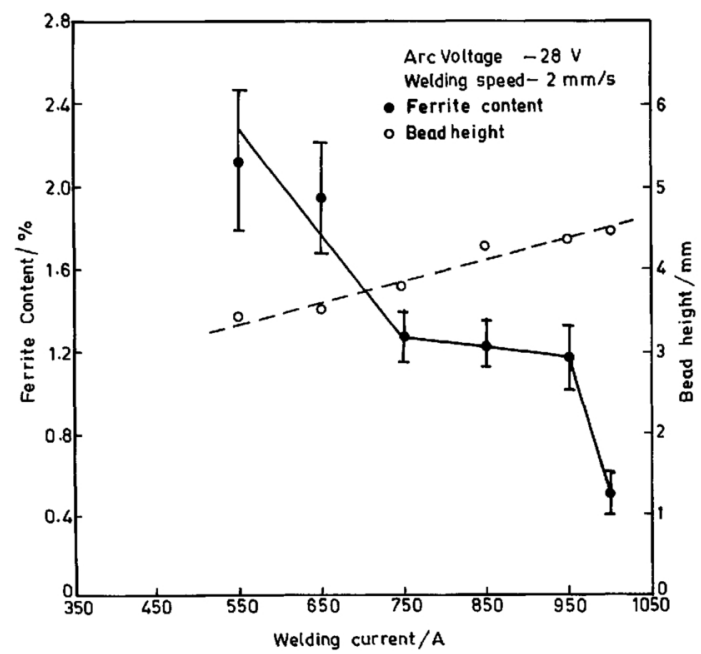

Fig. 1 Effect of variation in welding current on the bead height and the ferrite content of the cladding surface. 


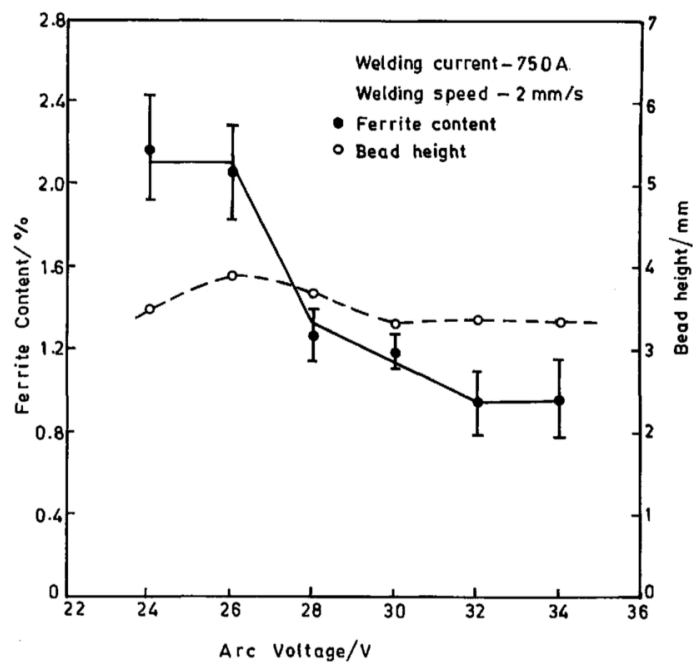

Fig. 2 Effect of variation in arc voltage on the bead height and the ferrite content of the cladding surface.

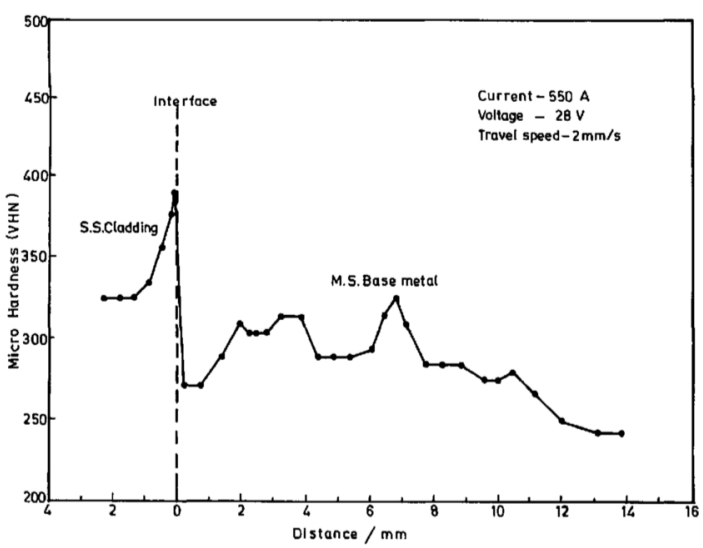

Fig. 3 The variation of microhardness across the weld deposited at the welding current of $550 \mathrm{~A}$, arc voltage of $28 \mathrm{~V}$ and travel speed of $2 \mathrm{~mm} / \mathrm{s}$.

Figures 3 and 4 show the variation of microhardness in deposited metal as well as in claddings adjacent to the base metal deposited at 550 and $1000 \mathrm{~A}$ respectively. Where, other parameters such as the arc voltage and travel speed are kept constant at $28 \mathrm{~V}$ and $2 \mathrm{~mm} / \mathrm{s}$ respectively. The figures depict that the microhardness of the deposited metal as well as that of the interface is significantly higher at higher welding current. The variation of microhardness in deposited metal as well as adjacent to base metal of claddings deposited at 24 and $34 \mathrm{~V}$ at a given current of $750 \mathrm{~A}$ and travel speed of $2 \mathrm{~mm} / \mathrm{s}$ is shown in Fig. 5 and

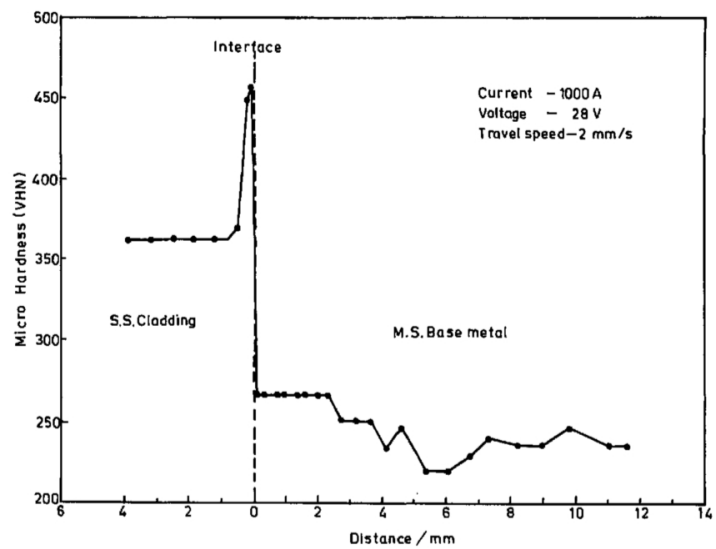

Fig. 4 The variation of microhardness across the weld deposited at the welding current of $1000 \mathrm{~A}$, arc voltage of $28 \mathrm{~V}$ and travel speed of $2 \mathrm{~mm} / \mathrm{s}$.

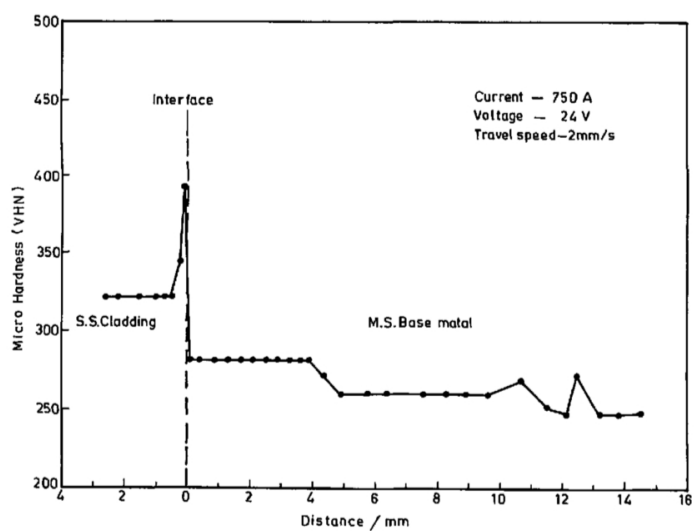

Fig. 5 The variation of microhardness across the weld deposited at the welding current of $750 \mathrm{~A}$, arc voltage of $24 \mathrm{~V}$ and travel speed of $2 \mathrm{~mm} / \mathrm{s}$.

Fig. 6 respectively. From these figures it is clear that the microhardness of deposited metal as well as that of the interface is significantly higher at higher arc voltage.

The microstructure of the weld-base metal interface produced during cladding at the lowest heat input of $6.55 \mathrm{~kJ} / \mathrm{mm}$ used in this work at the welding parameters of $550 \mathrm{~A}, 28 \mathrm{~V}$ and 2 $\mathrm{mm} / \mathrm{s}$ assuming the efficiency of $85 \%$ has been shown in Fig. 7. The microstructure reveals the formation of a transition region at the interface of the stainless steel and base metal. The typical presence of ferrite as small islands in the microstructure of stainless steel cladding is shown in Fig. 8. 


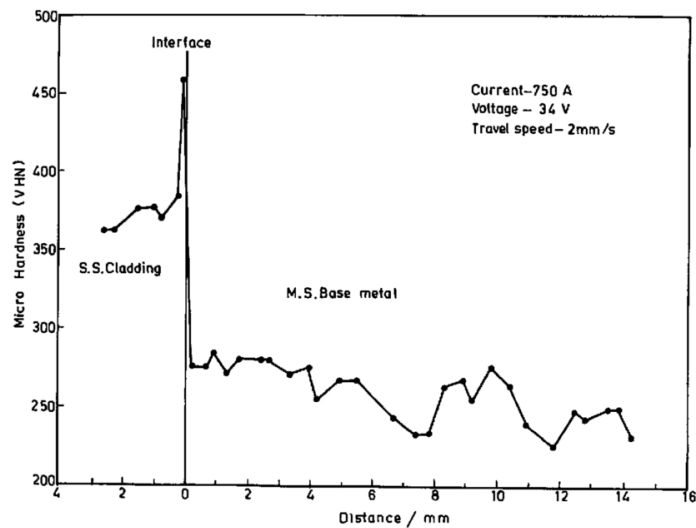

Fig. 6 The variation of microhardness across the weld deposited at the welding current of $750 \mathrm{~A}$, arc voltage of $34 \mathrm{~V}$ and travel speed of $2 \mathrm{~mm} / \mathrm{s}$.

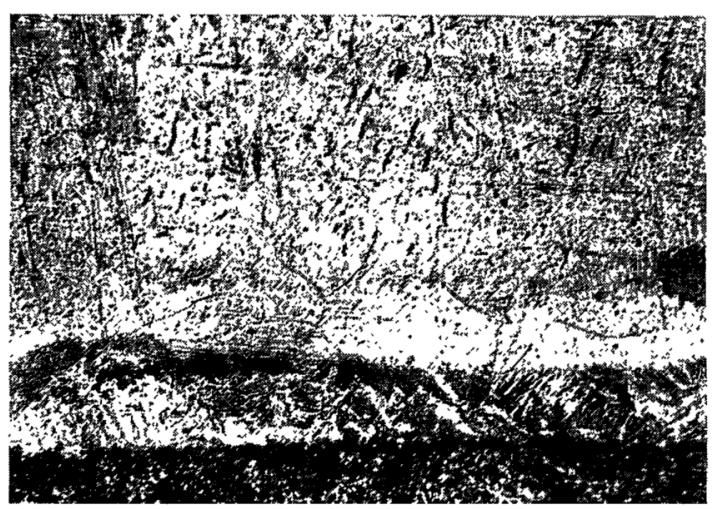

Fig. 7 Typical microstructure of weld-base metal interface showing a transition region at the interface. $(\times 100)$

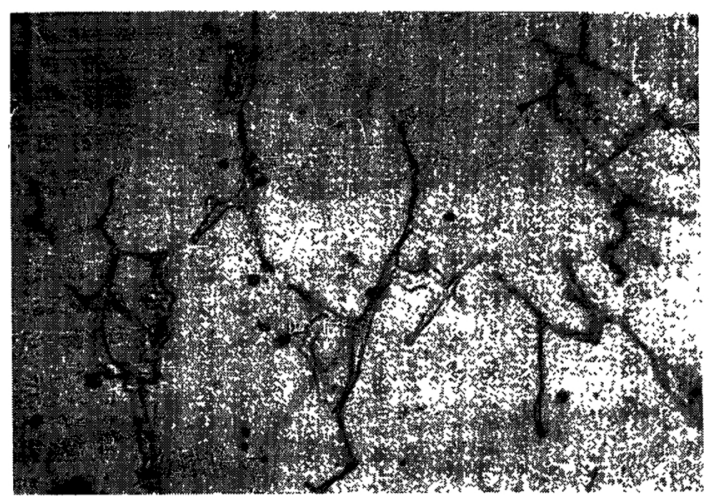

Fig. 8 Typical microstructure of the stainless steel cladding showing the presence of ferrite as small islands in the matrix. $(\times 250)$

\section{Discussion}

The ferrite content of austenitic stainless steel as typically shown in the micrograph presented in Fig. 8 is primarily dependent on its chemical composition where the chromium, silicon and carbon act as a ferrite stabiliser and nickel and manganese stabilise the austenite in the microstructure. The reduction in ferrite content of the clad surface with the increase in welding current and arc voltage as shown in Fig. 1 and Fig. 2 respectively many have primarily occurred due to a decrease in the potential ferrite stabilising element chromium in the stainless steel overlay as shown in Table 4. However, the role of other elements cannot be overruled. The significantly slower rate of variation of the ferrite level with the increase in welding current between 750 and 950 A (Fig. 1) is observed when the heat input is lying in the range of about $9.0-11.0 \mathrm{~kJ} / \mathrm{mm}$. It is interesting to note that in the similar range of heat input during variation of arc voltage between 28 and $34 \mathrm{~V}$ (Fig. 2) also a same nature of minor variation in ferrite content of the deposit is observed. In this region of heat input some transition phenomena in respect to the transformation of ferrite from austenite may have occurred which has been reduced the rate of variation of the ferrite level of the deposit. A further investigation is required in this range of heat input to understand this behaviour.

The increase in bead height with the increase in welding current (Fig. 1) at a given are voltage of $28 \mathrm{~V}$ and a welding speed of $2 \mathrm{~mm} / \mathrm{s}$ can be attributed to the increase in melting rate owing to higher energy input. However, with the increase in arc voltage (24-34 V) inspite of an moderate increase in energy input the bead height has not been found to increase significantly (Fig. 2) because the increase in arc voltage enhances the arc length and consequently increase the bead width almost linearly ${ }^{(6)}$.

The loss in chromium, nickel, manganese and silicon in the stainless steel as shown in Table 4 may have been caused primarily due to the burning at high arcing temperature and also due to the effect of dilution which 
increases significantly with the increase in welding current and moderately with the increase in arc voltage ${ }^{(6)}$. The increase of carbon in the stainless steel overlay with the increase in welding current and also with the increase in arc voltage as shown in Table 4 are attributed to the enhancement of dilution into the stainless steel from the base metal with the rise in heat input.

The diffusion of the carbon, from the base metal to the stainless steel, which increases with increase in heat input is responsible for the formation of the transition region of martensitic structure at the interface of the stainless steel and base metal as typically shown in Fig. 7. The formation of alloy carbides also in this region cannot be denied. This phenomena may have raised the microhardness of the interface of the cladding even up to 458 VHN as shown in Fig. 4 when the welding was carried out at a current of $1000 \mathrm{~A}$, a voltage of $28 \mathrm{~V}$ and a travel speed of $2 \mathrm{~mm} / \mathrm{s}$ having a heat input estimated as $11.9 \mathrm{~kJ} / \mathrm{mm}$. Similarly during welding with a high arc voltage of $34 \mathrm{~V}$ having welding current of $750 \mathrm{~A}$ and travel speed of $2 \mathrm{~mm} / \mathrm{s}$, the high heat input of the order of $10.84 \mathrm{~kJ} / \mathrm{mm}$ has resulted in higher microhardness of the interface (Fig. 6) which is nearly of the same order as mentioned above. However, in case of cladding with lower welding current of $550 \mathrm{~A}$ and arc voltage of $28 \mathrm{~V}$ and also where the cladding has been carried out at the welding current of $750 \mathrm{~A}$ and arc voltage of $24 \mathrm{~V}$ due to lower heat input of the order of $6.55 \mathrm{~kJ} / \mathrm{mm}$ and $7.65 \mathrm{~kJ} / \mathrm{mm}$ respectively the microhardness of their interfaces have been observed comparatively lower, lying in the range of $390 \mathrm{VHN}$ as shown in Fig. 3 and Fig. 5 respectively.

\section{Conclusion}

The increase in welding current considerably increases the thickness of deposit but the variation in arc voltage does not have a significant effect on it. The ferrite content of the stainless steel clad surface is primarily governed by its chemical composition which, to a great extent is determined by the heat input during welding. During deposition of stainless steel on carbon steel a transition region of considerably higher hardness than that of its surrounding forms at the interface. The hardness of the interface enhances even up to an order of $450 \mathrm{VHN}$ in case of an heat input in the range of about $11-12 \mathrm{~kJ} / \mathrm{mm}$.

\section{REFERENCES}

(1) American Welding Society (AWS) Handbook, Applied Liners and Weld Cladding, Vol, 3, 94.1.

(2) G. Almquist and N. Egeman: Welding and Metal Fabrication, Feb. (1963), 294.

(3) A. B. Marshall, M. F. Jordan and J. L. Aston: Welding and Metal Fabrication, 41, August (1973), 292.

(4) A. M. Horsefield, G. Almqvist and C. H. Rosendahl: British Welding Journal, May (1966), 315.

(5) A. F. Gifford and N. Smith: Stainless Cladding of Pressure Vessels by Fusion Welding Techniques, Procd. Second Commonwealth Welding Conf. (1965).

(6) P. K. Ghosh, P. C. Gupta, C. L. Raina and R. K. Gupta: Procd. National Welding Seminar (Welding -85), Indian Institute of Welding, Calcutta, (1985), 138-1.

(7) A. F. Bush and P. Colvin: Welding and Metal Fabrication, June (1969), 234.

(8) American Welding Society Handbook, Vol. 1, 518.

(9) C. Pohle and Eva-Maria Langer: Schweissen \& Schneiden, 7 (1986), E 102. 